\title{
EL INGENIOSOHIDALCO
}

\section{Eduardo Langagine}

\author{
Don Miguel de Cervantes, \\ anciano ya \\ y manco y desdentado, \\ inicia la lección mayor \\ de nuestra vida: \\ un octosílabo \\ que todos repetimos
}

En un lugar de La Mancha.

Agrega un endecasílabo clásico y formal

de cuyo nombre no quiero acordarme, acaso más culto y refinado.

El primero es popular,

$$
\begin{aligned}
& \text { ibérico, } \\
& \text { castellano, } \\
& \text { manchego, }
\end{aligned}
$$

el otro

importado

por Boscán y Garcilaso

desde la bota

que los mapas calzan

con orgullo milenario.

¿Es la mala memoria voluntaria

de cuyo nombre no quiero acordarme,

o es el culto lirismo

del mester de clerecía?
El primero lo cantan

los juglares

acompañados

de un laúd que tañe

agudo

como un refrán

sentencioso.

Es la voz popular

la que da inicio

a la más portentosa

lección de nuestro idioma.

Eduardo Langagne es miembro del snCA. Autor de Verdad posible (FCE, premio especial José Lezama Lima 2016 de Casa de las Américas), Tiempo ganado (UNAM) y No todas las cosas. Antología personal 1980-2015 (Fondo Editorial Estado de México). 